Danko Garić ${ }^{1}$

Sanja Filipović ${ }^{2}$
JEL: F3; E42; 024

DOI: 10.5937/industrija47-21848

UDC: $336.747 .4(510)$

Scientific Review

\title{
What are the prospects of the Yuan becoming the World's new Reserve Currency? ${ }^{3}$
}

\author{
Article history: \\ Received: 1 April 2019 \\ Sent for revision: 9 April 2019 \\ Received in revised form: 1 July 2019 \\ Accepted: 1 July 2019 \\ Available online: 4 July 2019
}

Abstract: China has long been the world's second largest economy, with the largest foreign exchange reserves and the second largest share in world trade. However, its position in the global economy has long been recognized, but this recognition has not been accompanied by the international monetary significance of the yuan. Despite China's economic significance, the political importance and the voting power in the International Monetary Fund (IMF) cannot be compared to that of the U.S. because the U.S. has over $17 \%$ of the votes, whereas China has $3.8 \%$. Owing to that, the U.S., together with its allies, gets to block decisions and tailor global economic policy. Striving to establish the world's reserve currency, China has been leading comprehensive economic and trade policies while strengthening the yuan convertibility. As a result, effective October 1, 2016, the yuan has become a reserve currency in the basket of special drawing rights along with the dollar, the euro, the yen, and the British pound. China has been supporting the IMF reform while establishing new institutions aimed at redefining the current international policy under the strong influence of the U.S. The paper analyses the channels of Chinese authorities' actions and the prospect of recomposing the international monetary system and reducing the global U.S. influence, with the aim of identifying whether it is likely that the Chinese currency will obtain the status of the world currency.

\footnotetext{
${ }^{1}$ University Educons, Faculty of Business Economics, Sremska Kamenica

${ }^{2}$ Economics Institute and Singidunum University, sfilipovic@singidunum.ac.rs

${ }^{3}$ The paper presents the results of a study conducted as a part of the projects 47009 and 179011 funded by the Ministry of Education, Science and Technological Development, Republic of Serbia.
} 
Garić D., Filipović S.: What are the prospects of the Yuan becoming the World's new...

Keywords: international monetary system, the yuan, the dollar, China, the U.S.

\section{Ima li izgleda da Juan bude nova svetska rezervna valuta?}

Apstrakt: Kina je već dugo druga najveća ekonomija sveta, sa najvećim deviznim rezervama i drugim najvećim učešćem u svetskoj trgovini. Pa ipak, njen položaj u globalnoj privredi dugi niz godina nije pratio međunarodni monetarni značaj juana. Uprkos ekonomskom značaju Kine, politički značaj $i$ učešće u glasovima Međunarodnog monetarnog fonda (MMF) ne može da se poredi jer SAD ima preko $17 \%$ glasova, a Kina 3,8\%. Zahvaljujući tome SAD zajedno sa saveznicima blokira odluke i kroji globalnu ekonomsku politiku. $U$ borbi da postane rezervna svetska valuta, Kina je vodila ekspanzivnu ekonomsku i trgovinsku politiku i paralelno je jačala konvertibilnost juana. Zahvaljujući tome, juan je od 1. oktobra 2016. godine postao rezervna valuta u korpi specijalnih prava vučenja zajedno sa dolarom, evrom, jenom $i$ britanskom funtom. Kina se zalaže za reformu MMF i paralelno formira nove institucije čija je funkcija prekrajanje aktualne međunarodne politike pod snažnim uticajem SAD. Rad analizira kanale delovanja kineskih vlasti $i$ perspektivu za prekomponovanja međunarodnog monetarnog sistema $i$ smanjenja globalnog američkog uticaja sa ciljem da se sagledaju mogućnosti da li ima izgleda da kineska valuta dobije status svetske valute.

Ključne reči: međunarodni monetarni sistem, juan, dolar, Kina, SAD.

\section{Introduction}

In the long history of money, the significance of certain currencies has changed. The Portuguese, Spanish, Dutch, French, British, and American national currencies have all had periods of domination in world trade and finance.

China was the first in history to use paper money back in the 10th century, whereas the present national currency of China (the yuan renminbi) was established in 1949 after the founding of the People's Republic of China. Owing to the strong economic growth in the past decades, China has been striving for internationalization of its national currency in the last two decades.

As a precondition for internationalization, a currency has to fulfill three essential functions (medium of exchange, store of value and unit of account) both for monetary authorities and for private entities (Krugman, Obstfeld, 2009). As a medium of exchange, a currency should enable private entities to make payments in international transactions, while it should serve monetary authorities for foreign exchange interventions. As a store of value, a currency 
Garić D., Filipović S.: What are the prospects of the Yuan becoming the World's new...

is used as investment assets by private entities, whereas central banks use it for foreign exchange reserves. Money, as a unit of account, should enable private entities to denominate international economic transactions and should provide monetary authorities with an anchor currency to peg their currencies, i.e. determine the exchange rate. The American dollar is presently the only currency that combines all six roles. The euro and the yen encompass all these functions but in a geographically limited space.

Countries with international currency have multiple benefits. First, residents of such countries may perform all international economic transactions in their national currency, thereby reducing transaction costs and the exchange rate risk. The country issuing an international currency makes the issuer's profit and has the opportunity to borrow in its currency at a low interest rate. Therefore, the United States continually has higher income on overseas (international) investments as compared to the expenditures on its debts. Overall, the countries whose national currencies are internationalized have stronger political and negotiating power. The prevalence and widespread use of the pound before World War I enabled Great Britain to finance expensive foreign military interventions, but after losing its status in World War II, it had to rely on the U.S. Ioans (Boston University, 2014; Kirshner, 1995). The gradual loss of the international reserve currency status for the British pound was at the same time the loss of its projection of political and military power abroad, which has led Great Britain to fall from an imperialist to a pauperized country (Cohen, 2015).

Nevertheless, the reserve currency status has some drawbacks as well. With such a status, the demand for financial assets denominated in that currency would increase, thereby creating appreciation pressures. Japan and Switzerland felt these pressures when many investors sought a safe haven in 2012. Since the issuer of a reserve currency should provide liquidity of the world market that may put pressure on a current account deficit (Malović, 2014). Bearing in mind the benefits of its currency internationalization, and the growing importance in the economy, China has fought for internationalization of its currency since 2000.

In order for a currency to be internationalized, it has to meet specific factors that can be grouped into three general categories: trust, liquidity, and transaction network (Helleiner, 2008). Trust in the stability of currency value is very important for its international use because the instability of currency value increases the possession risk and lowers its attractiveness as a store of value. Trust in the currency stability can be affected by several different factors, including fiscal and monetary policy, as well as the current account balance of the country issuing the international currency and its net debt position which affects the solvency risk (Tavlas, \& Ozeki, 1992). 
Garić D., Filipović S.: What are the prospects of the Yuan becoming the World's new...

International usage of a currency is also affected by the size of the issuing country's transaction network in the world economy, as benefits increase with the number of participants. An additional factor affecting the integration of the issuing country into the world economy is the economic size. International usage of a currency is nonlinear against the economic size of the issuing country. Thus, for example, the presence of the U.S. dollar in foreign exchange reserves is somewhat above $63 \%$, and the share of the U.S. economy in the global GDP is around 25\% (IMF, 2015).

Liquidity is an essential economic attribute of an international currency, as both private and public factors want to possess such money in the form of liquid interest-bearing assets rather than just as a currency. The existence of a well-developed and open financial market in the country of issue reduces the transaction cost (IMF, 2006). In order to gain the status of the international currency, equity and monetary market in the issuing country should be not only open but also very developed. Development of a country's financial market is one of the most important determinants of the currency's international status and is weighted from three aspects of financial market development: breadth, depth, and liquidity. Market breadth implies the availability of a wide range of financial instruments. To make a currency attractive, central banks and large financial institutions need securities denominated in the national currency. Market depth involves a vast array of financial instruments, which results in a certain level of market stability (Forbes, 2009). Market liquidity is reflected in a large volume of trading in financial assets, which gives investors assurance that they can safely sell the assets whenever they want. Therefore, these three aspects are significant in assessing the readiness of the country's financial sector to cope with the open capital account and the possibility to obtain the status of a reserve currency.

Military range, as a factor which has direct impact through the political influence of the issuing country, is also essential for currency internationalization. America's military supremacy that has existed since World War II is an important reason why the dollar remained the leading international currency (Posen, 2008). Although there are qualitative alternatives to the dollar, there is no alternative to the U.S. military supremacy. The U.S. may offer protection to governments abroad and still be a safe haven for investors.

\section{How did the U.S. dollar become a reserve currency?}

Throughout history, the significance of individual currencies in the world economy has been changing. In the 17th and 18th centuries, when the Dutch were a leading trading and financial power and when Amsterdam was the 
Garić D., Filipović S.: What are the prospects of the Yuan becoming the World's new...

leading international financial center, receivables in paper currency were becoming increasingly important (Wilson, 1977), and the Dutch guilder became the world's currency due to the dominance of the Dutch East India Company. The guilder was a reference unit for commercial transactions throughout Europe and a high-quality store of value (Quinn \& Roberds, 2016).

At the same time, the importance of the British pound increased, and several factors contributed thereto. First, the establishment of the Bank of England in 1694 improved the borrowing conditions of the British government and contributed to the strengthening of Great Britain's economic and military superiority. At the time of struggle for the supremacy between the respective military forces (Avner, Milgrom, Weingast, 1994), it was almost impossible for the government to provide funding at an interest rate of $8 \%$ for the construction of the English navy. However, the Bank of England provided the funds in 10 days (Clapham, 2008), and in return was granted the exclusive right to issue banknotes in the amount of the bank's capital (Lawrence, 1997). As a result of the Peel Banking Act of 1844, the Bank of England was granted a monopoly on the printing of banknotes in Great Britain. That strengthened its status as a central bank but did not give it the role of a lender of last resort until 1870 (CAPI, Goodheart, \& Schnadt, 1995).

One of the crucial factors that provided the pound with the reserve-currency status is the fact that Great Britain was a trading superpower of that time, which in 1860 absorbed 30\% of world exports (Imlah, 1958). Owing to that, in the period 1860-1914 about $60 \%$ of world trade was invoiced in pounds sterling and, at the end of 1913, half of the world's foreign exchange reserves were denominated in pounds sterling (Princeton University, 1969). Great Britain was the world's largest creditor, and London was the world's financial hub.

Since the 1870s, the U.S. economy, measured in GDP, has been larger than the British economy. In 1913, the U.S. surpassed Great Britain in foreign trade as well, although a larger part of the trade was not denominated in dollars but in pounds sterling (Ganziro, \& Vambery, 2016). Central banks then began to hold dollar reserves in their assets, and in the structure of world currency reserves the dollar took the lead in the mid-1920s (BIS, 2010). The U.S. became the world's largest creditor after World War I, taking over that position from Great Britain which had been, until then, the world's leading financier who financed the U.S. as well.

The international role of the dollar rose with the development of the financial market. During World War I, the U.S. was crediting Great Britain, thereby strengthening the position of the dollar. Four decades after overtaking Great Britain's economy in GDP terms, the dollar has reached the status held by the pound. The reason for such a long period of the pound descend can certainly 
Garić D., Filipović S.: What are the prospects of the Yuan becoming the World's new...

be explained by general inertia because the pound was used by default (Krugman, 1984).

As a result of the necessity to create a new international monetary system, the International Monetary Fund (IMF) was established in Bretton Woods in 1944 to help countries overcome BoP imbalances, and the dollar was officially declared the leading international currency. The system was based on the dollar's convertibility into gold (35 USD per ounce of gold), and other currencies had a specific exchange rate against the dollar. The dollar's convertibility into gold gave peace of mind to central banks that held foreign exchange reserves mostly in this currency. Within the regime of fixed exchange rates, the dollar became a world's reserve currency.

After signing the agreement, the increase in world trade and low inflation were actually achieved, but there was also strong GDP growth in the countries of devastated Europe, and particularly in Japan. The downsides of this system were limited capital flows (Yeager, 1976) and loss of the control over monetary policy (Bordo, \& Kydland, 1995).

As early as in the 1960s, due to the budget deficits resulting from the financing of the Vietnam War and foreign trade deficits, Triffin pointed to the beginning of the end of the Bretton Woods system which was based on the confidence in the dollar. The "Triffin dilemma" was questioning the U.S. ability to continue the financing of the current account deficit without putting pressure on the dollar and the gold reserves outflow (Princeton University, 1978). In 1971, the U.S. President Richard Nixon unilaterally suspended the convertibility of the dollar into gold. The era of the Bretton Woods and the dollar-to-gold system was finished and was followed by the floating exchange rate regime in which currencies were not pegged to gold.

Still, after these changes, the dollar did not lose the status of the world's leading currency but maintained the dominant position, confirming that the international status of a currency is closely related to the international status of the issuing country (Eichengreen, 2011). The U.S. was then the world's largest economy whereas Japan and Germany, ranking second and third, respectively, were the export-oriented economies, none of which were willing to use their currencies as a reserve because they would appreciate, thus making their exports more expensive. According to the 1973 agreement reached between the U.S. President Nixon and Saudi King Faisal, in exchange for the U.S. military protection Saudi Arabia shall accept the dollar as the only means of oil payments and shall invest the surplus profit in the U.S. public bonds (Casey Research, 2014). By 1975, all members of OPEC agreed to sell their oil in dollars and invest in industrialized countries (IMF, 2008). Instead of being backed by gold, the dollar was backed by "black gold", i.e. oil (Cao, 2016). It was the beginning of the petrodollar system (Kapor, 2010) which allowed the circulation of dollars, while the artificial demand for 
Garić D., Filipović S.: What are the prospects of the Yuan becoming the World's new...

the U.S. dollar was secured by the increasing demand for oil (Sequence Evolutions, 2014).

The dollar imposed itself as the most liquid assets and safe haven at the time of the global economic crisis. In the period July-October 2008, the dollar appreciated $21 \%$ against the euro. Status of the dollar is also evident in Table 1 from the structure of foreign exchange reserves of central banks which strive to keep the safest and most liquid assets.

Table 1 Structure of the world's foreign exchange reserves

\begin{tabular}{|c|c|c|c|c|c|c|c|}
\hline \multirow{2}{*}{$\begin{array}{l}\text { Total } \\
\text { foreign } \\
\text { exchange } \\
\text { reserves } \\
\text { (in USD } \\
\text { bln) }\end{array}$} & \multirow{2}{*}{$\begin{array}{l}\text { Allocated } \\
\text { foreign } \\
\text { exchange } \\
\text { reserves (in } \\
\text { USD bln) }\end{array}$} & \multicolumn{6}{|c|}{ Currency structure of foreign exchange reserves (\%) } \\
\hline & & Dollar & Euro & Yen & Pound & Swiss Franc & Yuan \\
\hline \multicolumn{8}{|c|}{ End of 2000} \\
\hline 1.936 & $1.518(78,5)$ & 71.1 & 18.3 & 6.0 & 2.8 & 0.3 & - \\
\hline \multicolumn{8}{|c|}{ Beginning of 2017} \\
\hline 10.902 & $8.848(81,2)$ & 64.5 & 19.3 & 4.6 & 4.3 & 0.2 & 0.9 \\
\hline
\end{tabular}

Source: International Monetary Fund

\section{Prospects of the yuan as an international currency}

In order to observe prospects and the present role of the yuan, three different and yet associated aspects will be analyzed - capital account openness, the means of international exchange and a reserve currency (Brookings Institution, 2016).

\subsection{Capital account openness}

Capital account openness implies a degree of freedom with which investors can transfer their capital internationally. Capital account openness is determined by the regulatory framework and compliance with the control process, hence the different actual and legal openness of the capital account.

The ratio of external assets and liabilities to GDP, which determines the international investment position of a country, is used to measure the actual openness of a capital account. China's external assets relate to the total assets of Chinese households, enterprises, financial institutions, and governments. External liabilities are the total value of foreign investment in China, along with the financial obligations of Chinese households, enterprises, and government towards foreign entities. Over the past decade, China's 
Garić D., Filipović S.: What are the prospects of the Yuan becoming the World's new...

external assets and liabilities have increased six times and cover almost $100 \%$ of GDP (Kose, Prasad, Rogoff, \& Wei, 2006), but still lag behind the economies of reserve currencies in the U.S. and Japan (IZA, 2012). At the end of 2017, external assets and liabilities of the U.S. amounted to $326 \%$ of GDP; of Japan, $310 \%$ of GDP; and $442 \%$ of GDP in Eurozone.

The structure of external assets is dominated by foreign direct investment $(62 \%)$, followed by the portfolio investment $(13 \%)$, while the portfolio debt and other investments (banking and trade loans) amount to 25\% (Ma \& McCauley, 2013).

The irony of the structure of China's external balance rests on China's international payments for the privilege of owning more assets than liabilities. Thus, unlike the U.S., which is a net external debtor (Meyer, 1989) but has a positive net investment income (Bruegel, 2017), China has a negative net investment income. That is because the People's Bank of China has a high level of foreign exchange reserves. The high level of foreign exchange reserves (about $55 \%$ of external assets) results from limitations on capital flow. The population has a narrow choice for diversification of savings into foreign assets, and Chinese companies are expanding abroad through acquisitions and establishment of branches. For the past ten years, FDls of Chinese companies have reported increased participation in external assets from $5 \%$ to $18 \%$.

The question arises as to why China would liberalize the capital account. China does not need foreign capital flows because it has a high savings rate (46\% of GDP in 2016 - IMF data), the largest foreign currency reserves in the world, and it exports domestic savings. It is, therefore, reasonable that China wants to have control over capital flows and a more significant geopolitical influence. On the other hand, by liberalizing the capital account, China can achieve several beneficial effects. First of all, trading volume increases. The entry of foreign capital could increase productivity, improve the operating processes and technology transfer, and could strengthen the status of Shanghai as an international financial center. The entry of foreign banks could increase competition in the banking sector and improve banking products, risk management, and other innovations (Prasad, 2009).

\subsection{The means of international exchange}

Since the mid-2000, China has been gradually promoting the internationalization of the yuan. The promotion started on the sophisticated financial market of Hong Kong, which is characterized by strong institutions. With the increase in the volume of trade, the issue was whether trade, which in 2015 grew by about $127 \%$ compared to the previous year, should be calculated in yuan. China's position as the world's second largest trader 
Garić D., Filipović S.: What are the prospects of the Yuan becoming the World's new...

(exports and imports), has allowed a noticeable increase in the yuan's share in China's foreign trade.

Using the yuan in trade calculations is a logical step in the internationalization of the currency. In 2015, the trading volume invoiced in the yuan amounted to 1.100 billion dollars, i.e. about $30 \%$ of the total foreign trade. However, since 2015, the yuan has depreciated against the dollar with a declining interest in the calculation of trade in yuan.

The increasing international role of the yuan has been confirmed by the SWIFT (Association for International Interbank Financial Telecommunications) data, indicating that the yuan's share in international transactions has grown from $0.3 \%$ at the end of 2011 to a maximum of $2.8 \%$ in August 2015 . However, these data are incomplete because, on the one hand, they do not take into account all transactions, and on the other hand, they calculate some transitions multiple times.

The pace at which the yuan is internationalized will also depend on its usage in international financial transactions. Compared to 2013 when it stood at $2.2 \%$ (out of $200 \%$ ), in April 2016 the yuan's share increased to $4 \%$ of trading in the global foreign exchange market (BIS, 2016). The dollar's share amounted to $87.6 \%$ and the euro's to $31.3 \%$ in the same month. The yuan has a significant share in foreign exchange, but relative to main reserve currencies, such a share is still small.

The liquidity level of the world economy, as well as the number of financial centers available for clearing transactions, are essential for the widespread, global use of the yuan (Chatham House, 2012). China has promoted the internationalization by increasing the number of such financial centers.

\subsection{The yuan as a reserve currency}

An important contribution to achieving the status of a reserve currency is an increase in yuan-denominated bond issuance in the international financial market, known as dim sum bonds. These bonds were first issued in Hong Kong, which is the largest market of the yuan bonds outside of mainland China. The amount of outstanding dim sum bonds in October 2015 stood at about 56 billion dollars, and $40 \%$ of this amount was issued by foreign government agencies, banks, and companies from China. Also, about $40 \%$ of the issue is related to multinational companies from Germany, South Korea, and the U.S. Great Britain is the first country to issue yuan-denominated bonds. The People's Bank of China issued dim sum bonds for the first time in October 2015 in London. In December 2015, South Korea became the first country to issue the so-called "Panda bonds" in mainland China, thus providing domestic investors with the possibility of portfolio diversification. 
Garić D., Filipović S.: What are the prospects of the Yuan becoming the World's new...

In order to persuade the IMF to put the yuan into the currency basket, China has taken the specific steps in the financial market and carried out the capital account reforms in 2015. The upper limit on deposit interest rates was suspended, and the banks were allowed to determine the interest rates on deposits and loans independently. In August 2015, market forces were allowed to determine the yuan exchange rate, which is very important for including the yuan in the IMF's currency basket.

\section{Parallel institutions}

On November 30, 2015, the IMF announced that the yuan has satisfied all the preconditions and that, effective October 1, 2016, it will become the fifth currency included in the Special Drawing Rights (IMF, 2015-2) along with the dollar, the euro, the yen, and the British pound. Thus, the share and significance of other reserve currencies recorded a decrease $-41.73 \%$ for the dollar, $30.93 \%$ for the euro, 10.92 for the yuan, $8.33 \%$ for the yen and $8.09 \%$ for the British pound. Owing to that, the Central Bank of China acquires the right to seigniorage (the difference between the value of money and the price of its production) and the inflation tax (inflation increase reduces government debt incurred by issuing bonds). Each central bank realizes these revenues, but the country issuing a reserve currency has additional income collected from foreign citizens (Filipović, \& Garić, 2014).

The status of a reserve currency will bring China a capital inflow from the investment funds, private companies, and individual investors. The danger may rest in appreciation of the yuan exchange rate, which could weaken the exports. Therefore, China will gradually start to transform into a financial economy, but that model requires the military security of the currency, similar to what Great Britain and later the U.S. had throughout history.

Even after the yuan has gained the status of a reserve currency, China will continue to insist on reforming the IMF (Đorđević, \& Trapara, 2017). Regardless of this, China has decided to form new multilateral institutions in addition to strengthening its role in the existing ones (Brookings Institution, 2017).

Such institution is an association of BRICS (an acronym for Brazil, Russia, India, China, and South Africa) countries, which together account for about a quarter of world GDP and about two-fifths of the world's population (Filipović, \& Garic, 2015). China has decided to strengthen the relations within the association but also to increase its influence in the world. To be taken seriously in the world of finance, this institution established the new development bank aimed at preventing potential currency crises in BRICS countries. 
Garić D., Filipović S.: What are the prospects of the Yuan becoming the World's new...

Another financial institution is the Multilateral Development Bank (AIIB - Asian Infrastructure Investment Bank), whose members are the world's leading economies (except the U.S. and Japan). The Bank aims to connect the countries of the region through the development and infrastructure projects (Mitrovic, \& Trailović, 2014) while reducing the excess capacity in the construction sector through the participation of Chinese companies. The Bank gives legitimacy to China's efforts to expand the spheres of economic and political influence, while insensibly changing rules of the game. Like the World Bank, the Bank does not grant loans from the capital of its members but borrows on the international financial market, thus providing the finance for loans.

\section{Conclusion}

China has been strengthening its economic and political position in international institutions for years, not only by being integrated into existing institutions under the current rules of the game but also by creating new institutions and changing the actors of the global economic scene according to its needs. The internationalization of the yuan is part of this process. China hopes the yuan will weaken the dollar's impact and take its fair share as one of the world's dominant reserve.

The share of the Chinese yuan in the world's foreign currency reserves is about $1 \%$, and it has come a long way in a short time. The yuan has made impressive progress in international finance. Entering the IMF currency basket is a symbolic but significant step because it has placed the yuan in the upper echelon of foreign currencies.

It is unlikely that the yuan will succeed in replacing the dollar, especially from the perspective of the poorly developed financial market and the capital account closed. The Communist Party is not an institution of trust outside of China, and the fear of losing their invested funds by a single decision of the Communist Party of China will surely keep the investors away from largescale investments in China's financial market. Nevertheless, securities from China are still attractive in terms of higher yield, so a certain level of interest in them will exist.

Unlike China, the U.S. is called safe haven and is considered a lender of last resort, which means that financial assets denominated in dollars, especially the U.S. Treasury bonds, are most reliable. In order to be considered safe, assets must be the first choice of panicked investors, and must also have a high level of liquidity. In order for a country's currency to be considered a safe haven, such country must have trustful institutions. 
Garić D., Filipović S.: What are the prospects of the Yuan becoming the World's new...

If analyzed a bit further, beyond the current moment but on the wave of current events, China is trying to strengthen its position in the world as much as possible, although $20 \%$ of its exports go to the U.S. market that is introducing taxes on its products, which may lead to a slowdown of China's economic growth. The growth may also be affected by the "fewer workers, more pensioners" trend, and it is therefore likely that the consumption in China will stagnate or decline. In 2013, China reported $13.7 \%$ of the population aged 60 and older (MPRA, 2013). According to the UN, a society in which $10 \%$ or more of the population is 60 and older is considered an aging society, and a burden on social security systems is typical for such societies.

In a situation with volatile consumption and exports, and hence economic growth, pressure for institutional reforms pile up and, therefore, the ability of China to internationalize the yuan becomes questionable because investors' trust in currency requires trustful institutions.

It is unlikely that the yuan will replace the dollar as the global reserve currency because there are many limitations on its more extensive usage and further internationalization. However, it is likely that the yuan will come to and remain at the level of other currencies from the basket of special drawing rights, and hence at the upper echelon of the world currencies.

\section{References}

-BIS, (2010). The Federal Reserve, the Bank of England and the Rise of the Dollar as an International Currency, 1914-39. BIS Working Paper, No. 328, Basel, Switzerland: Eichengreen, B., \& Flandreau, M.. doi:10.2139/ssrn.1717802

-BIS. (2016). Foreign exchange turnover in April 2016 (Triennial Central Bank Survey). Basel, Switzerland.

Bordo, M.D., \& Kydland, F.E. (1995). The Gold Standard As a Rule: An Essay in Exploration. Explorations in Economic History, 32(4), 423-464. doi:10.1006/exeh.1995.1019

-Boston University. (2014). Economic Statecraft and Power Redistribution during Wartime: Lessons from the Sterling Era and the Future of America's Military Might. Boston, USA.

Broz, J.L. (1997). The International Origins of the Federal Reserve System. Ithaca, USA: Cornell University Press.

Cao, L. (2016). Currency Wars and the Erosion of Dollar Hegemony. Michigan Journal of International Law, 38(1), 57-119. Retrieved from https://repository.law.umich.edu/mjil/.

Capie, F., Fischer, S., Goodhart, C., \& Schnadt, N. (1995). The development of central banking. In F. Capie, S. Fischer, C. Goodhart, \& N. Schnadt (Eds.), he Future of Central Banking: The Tercentenary Symposium of the Bank of England. Cambridge: Cambridge University Press (CUP). doi:10.1017/cbo9780511983696 
Garić D., Filipović S.: What are the prospects of the Yuan becoming the World's new...

-Casey Research. (2014). The Demise of the Petrodollar. Retrieved from https://www.caseyresearch.com/demise-of-the-petrodollar.

Chen, G., \& He, J. (2013). China should open immigration policy. Munchen, Germany: MPRA. (MPRA Paper No. 79607).

Clapham, J.H. (2008). The Bank of England: A History. Cambridge, UK: Cambridge University Press.

Cohen, B.J. (2015). Currency Power: Understanding Monetary Rivalry. Princeton: Walter de Gruyter GmbH. doi:10.1515/9781400873517

Darvas, Z., \& Huettl, P. (2017). Returns on foreign assets and liabilities: exorbitant privileges and stabilising adjustments. In Working Paper Issue 07. Brussels, Belgium: Bruegel.

Đorđević, B., \& Trapara, B. (2017). Instrumentalizacija međunarodnih institucija u uspostavljanju novog svetskog poretka. Srpska politička misao, 55, 29-55. Retrieved from http://www.ips.ac.rs.

-ECB. (2018). Euro area quarterly balance of payments and international investment position. Frankfurt, Germany: Press Release.

Eichengreen, B. (2011). Exorbitant Privilege: The Rise and Fall of the Dollar and the Future of the International monetary system. New York, USA: Oxford University Press.

Filipovic, S., \& Garic, D. (2014). Analysis of the cause of global balance of payment imbalance. Poslovna ekonomija, 8(2), 277-300. doi:10.5937/poseko1402277f

Filipović, S., \& Garić, D. (2015). Resursi irazvojna politika kao poluga uspeha zemalja BRIK-a. In Štednja ili potrošnja - recesija ili oporavak. Sremska Kamenica, Srbija: Univerzitet Edukons. (pp. 73-?).

Forbes, K.J. (2009). Financial Network Effects and Deepening. In J. Pisani-Ferry \& A. Posen (Eds.), The Euro at Ten: The Next Global Currency?. Washington DC, USA: Peterson Institute of International Economics. pp. 41-53.

Ganziro, T.T., \& Vambery, R.G. (2016). he Exorbitant Burden: The Impact of the U.S. Dollar's Reserve and Global Currency Status on the US twin-deficits. Emerald. doi:10.1108/9781785606403

Greif, A., Milgrom, P., \& Weingast, B.R. (1994). Coordination, Commitment, and Enforcement: The Case of the Merchant Guild. Journal of Political Economy, 102(4), 745-776. doi:10.1086/261953

Helleiner, E. (2008). Political determinants of international currencies: What future for the US dollar. Review of International Political Economy, 15(3), 354-378. doi:10.1080/09692290801928731

Howden, D., \& Zhou, Y. (2014). Unintended Consequences of China's One-Child Policy. Munchen, Germany: MPRA. (MPRA Paper No. 79607).

Ikenberry, J.G., \& Lim, D.J. (2017). China's emerging institutional statecraft, The Asian Infrastructure Investment Bank and the prospects for counter-hegemony (Project on International Order and Strategy). Washington DC, USA: Brookings Institution.

-IMF. (2015). Survey on the holdings of currencies in official foreign currency assets. Washington DC, USA.

-IMF. Review of the Method of Valuation of the SDR - Initial Considerations (Policy Papers). Washington DC, USA.

Imlah, A. (1958). Economic Elements in the Pax Britannica. Cambridge, USA: Harvard University Press. 
Garić D., Filipović S.: What are the prospects of the Yuan becoming the World's new...

Kapor, P. (2010). Kraj ere američkog dolara. Industrija, 38(2), 121-153. Retrieved from industry-jse.com..

Kirshner, J. (1995). Currency and Coercion: The Political Economy of International Monetary Power. New Jersey, USA: Princeton University Press.

Kose, M.A., Prasad, E., Rogoff, K., \& Wei, S. (2006). Financial Globalization: A Reappraisal. In Working Paper. Series 12484, 1-91. doi:10.3386/w12484

Krugman, P.R. (1984). The International Role of the Dollar: Theory and Prospects, Exchange Rate Theory and Practise. In J.F.O. Bilson \& R.C. Marston (Eds.), Exchange Rate Theory and Practice. Chicago, USA: University of Chicago. 261-278.

Krugman, P.R., \& Obstfeld, M. (2009). Međunarodna ekonomija: Teorija i politika. Beograd, Srbija: Data Status.

Lim, E. (2006). The Euro's Challenge to the Dollar: Different Views From Economists and Evidence From Cofer (Currency Composition of Foreign Exchange Reserves) and Other Data. IMF Working Papers, 06(153), 1. doi:10.5089/9781451864137.001

Lindert, P.H. (1969). Key Currencies and Gold 1900-1913. Princeton studies in International Finance, No. 24, Princeton, USA, Princeton University.

Ma, G., \& McCauley, R.N. (2013). Is China or India more financially open. BIS Working Paper, 410, 1-35. Retrieved from https://www.bis.org/list/wpapers/index.htm.

Malovic, M. (2014). To be or renminbi: Trend in the evolution of the international monetary system. Industrija, 42(3), 141-162. doi:10.5937/industrija42-6410

Meyer, S.A. (1989). The U. S. as a Debtor Country: Causes, Prospects and Policy Implications. Business Review, (Federal Reserve Bank of Philadelphia), November/December, 19-31..

Mitrović, D., \& Trailović, D. (2014). Geopolitika Kineske Energetske Strategije U Centralnoj Aziji. Srpska politička misao, 44(2), 133-155. doi:10.22182/spm.4422014.7

Momani, B. (2008). Gulf Cooperation Council Oil Exporters and the Future of the Dollar. New Political Economy, 13(3), 293-314. doi:10.1080/13563460802302594

Ozeki, Y., \& Tavlas, G. (1992). The Internationalization of Currencies: An Appraisal of the Japanese Yen. Washington, D.C.: International Monetary Fund (IMF). doi:10.5089/9781557751973.084

Posen, A.S. (2008). Why the Euro will Not Rival the Dollar. International Finance, 11(1), 75-100. doi:10.1111/j.1468-2362.2008.00217.x

Prasad, E.S. (2009). Is the Chinese growth miracle built to last. China Economic Review, 20(1), 103-123. doi:10.1016/j.chieco.2008.05.007

Prasad, E.S. (2016). China's Efforts to Expand the International Use of the Renminbi (U.S.-China Economic and Security Review Commission). Washington DC: Brookings Institution.

Prasad, E.S., \& Ye, L. (2012). The Renminbi's Role in the Global Monetary System. Bonn, Germany: IZA. (IZA DP No. 6335).

Quinn, S., \& Roberds, W. (2016). Death of a Reserve Currency. International Journal of Central Banking, 12(4); 63-103.

-Sequence Evolution. (2014). Petroleum and the Dollar - US dependency on the survival of the Petrodollar system. Retrieved from http://www.sequencenews.com/wordpress/petroleum-and-the-dollar-usdependency-on-the-survival-of-the-petrodollar-system/. 
Garić D., Filipović S.: What are the prospects of the Yuan becoming the World's new...

Stojanović, B. (2013). Međunarodne valute od tetradrahme do evra Treći deo: američki dolar i pojava evra. Bankarstvo,13(4), 13-37. Retrieved from http://www.ubsasb.com/Default.aspx?tabid=88..

Subacchi, P., \& Huang, H. (2012). The Connecting Dots of China's RMB Strategy: London and Hong Kong (Chatham House Briefing Paper). London, UK: Chatham House.

Triffin, R. (1978). Gold and the Dollar Crisis: Yesterday and Tomorrow. Essays in International Finance, No. 132, Princeton, USA, Princeton University.

Wiegand, J. (2008). Bank Recycling of Petro Dollars to Emerging Market Economies During the Current Oil Price Boom. IMF Working Papers, 08(180), 1. doi:10.5089/9781451870381.001

Wilson, C.H. (1977). Anglo-Dutch Commerce and Finance in the Eighteenth Century. New York, USA: Arno Press.

Xu, X., \& Han, A.S. (2018). Will China Collapse: A Review, Assessment and Outlook. In Hoover Institution Economics Working Paper 18104. Stanford, USA: Hoover Institution.

Yeager, L.B. (1976). International Monetary Relations: Theory, History, and Policy. New York, USA: Harper and Row.. 2nd ed. 